\title{
UJI STABILITAS FISIK FORMULASI LOTION ANTI NYAMUK MINYAK SEREH
}

\section{(PHYSICAL STABILITY TEST OF FORMULATION OF LEMONGRASS OIL ANTI MOSQUITO LOTION)}

\author{
YANI AMBARI $^{1}$, NI MADE DHARMA SHANTINI SUENA $^{2}$ \\ ${ }^{1}$ STIKES RS Anwar Medika \\ ${ }^{2}$ Fakultas Farmasi Universitas Mahasaraswati Denpasar
}

\begin{abstract}
Abstrak: Nyamuk adalah penyebar berbagai penyakit. Nyamuk adalah sumber transmisi demam berdarah, malaria, Chikungunya, dan ekstremitas (filariasis). Salah satu bahan alam yang memiliki potensi sebagai anti nyamuk adalah minyak Citronella (Citronella oil). Minyak Citronella mengandung minyak esensial dengan komponen geraniol (20-40\%), citronellal (25-50\%), dan citronellol (10-15) yang menimbulkan aroma, sehingga dapat digunakan sebagai repellent atau pengusir nyamuk. Minyak Citronella adalah insektisida alami murah dan efektif, juga dapat digunakan dengan aman dan praktis, sehingga dapat dikembangkan menjadi lotion anti nyamuk. Untuk menjaga stabilitas minyak Citronella dalam bentuk lotion, perlu formulasi lotion anti nyamuk yang tepat. Tujuan dari penelitian ini adalah untuk mengetahui formulasi lotion dari bahan aktif dari oleum Citronella dan untuk mengetahui hasil evaluasi dilakukan pada Lotion Citronella. Metode yang digunakan dalam pembuatan lotion Citronella adalah metode peleburan. Evaluasi dilakukan seminggu setelah pembuatan sediaan lotion, yaitu uji organoleptik, uji $\mathrm{pH}$, uji bobot jenis, uji homogenitas, uji daya sebar, dan uji ukuran partikel. Hasil evaluasi sediaan lotion minyak Citronella, antara lain, pada uji organoleptis lotion tidak berubah, tetap berwarna putih, memiliki bau khas Citronella dan tekstur lembut. Hasil pemeriksaan $\mathrm{pH}$, lotion tidak mengalami berubah $\mathrm{pH}$ yaitu tetap $\mathrm{pH}$ 7. Dalam uji daya sebar, lotion Citronella pada konsentrasi 18\% menyebar merata atau homogen. Hasil uji homogenitas, lotion Citronella pada konsentrasi 18\% tidak menunjukkan butiran kasar pada kaca transparan. Pada uji bobot jenis menggunakan alat Piknometer, diperoleh bobot jenis lotion Citronella adalah $23,8 \mathrm{~g} / \mathrm{ml}$. Terakhir pada uji ukuran partikel, lotion Citronella memiliki ukuran partikel yang seragam.
\end{abstract}

Kata kunci: lotion, nyamuk, Oleum Citronella, stabilitas fisik

\begin{abstract}
Mosquitoe is a spreader of various diseases. Mosquitoes are a source of transmission of dengue fever, malaria, chikungunya, and elephantiasis (filariasis). One plant that has the potential as anti mosquito is citronella oil (Oleum Citronella). Citronella fragrance contains essential oils with geraniol components (20$40 \%$ ), citronellal (25-50\%), and citronellol (10-15) which gives rise to aroma, so it can be used as a repellent or mosquito repellent. Citronella Oil is a cheap and effective natural insecticide, it can also be used safely and practically, so it can be developed into anti-mosquito lotion. To maintain the stability of citronella oil in the form of lotion, it needs the right formulation of anti mosquito lotion. The purpose of this experiment is to know the formulation of lotion from the active ingredient of oleum citronella and to know the result of evaluation done on the citronella lotion. The method used in the manufacture of citronella lotion is the melting method. The evaluation was performed a week after the preparation of the lotion preparation, including organoleptic test, $\mathrm{pH}$ test, density test, homogeneity test, spreading ability test, and particle size test. The results of the evaluation of lotion preparation with citronella active ingredients, on the organoleptis test lotion did not change the white lotion, has a distinctive smell of citronella and soft texture. Result of $\mathrm{pH}$ test, lotion did not change $\mathrm{pH}$ that is $\mathrm{pH}$ 7. In spreading test, citronella lotion at concentration $18 \%$ spread evenly or homogeneous. The result of homogeneity test, citronella lotion at $18 \%$ concentration did not show any coarse grain on transparent glass. In the density test using pycnometer tool obtained by weight of citronella lotion is $23,8 \mathrm{~g} / \mathrm{mL}$. Finally on the particle size test, citronella lotion has a uniform particle size.
\end{abstract}

Keywords:, lotion, mosquito, Oleum citronella, physical stability

\section{PENDAHULUAN}

Nyamuk adalah penyebar berbagai macam penyakit. Nyamuk merupakan sumber penularan penyakit demam berdarah, malaria, chikungunya, dan kaki gajah (filariasis). Nyamuk adalah serangga yang termasuk dalam Phylum Arthropoda, yaitu hewan yang tubuhnya bersegmen-segmen, mempunyai

\footnotetext{
• email korespondensi: yaniambari87@gmail.com
} 
rangka luar dan anggota garak yang berbuku-buku. Pada nyamuk betina, bagian mulutnya membentuk probosis panjang untuk menembus kulit mamalia untuk menghisap darah. Nyamuk betina memerlukan protein untuk pembentukan telur dan oleh karena diet nyamuk terdiri dari madu dan jus buah, yang tidak mengandung protein, kebanyakan nyamuk betina perlu menghisap darah untuk mendapatkan protein yang diperlukan. Nyamuk jantan berbeda dengan nyamuk betina, dengan bagian mulut yang tidak sesuai untuk menghisap darah (Suwito, 2010).

Nyamuk Ae. aegypti adalah vektor utama penyakit DBD di daerah tropik. Di Asia, Ae. aegypti merupakan satu-satunya vektor yang efektif menularkan DBD karena tempat perindukan berada di sekitar rumah dan hidupnya tergantung pada darah manusia. Pada daerah yang penduduknya jarang, $A e$. aegypti masih memiliki kemampuan penularan yang tinggi karena kebiasaan nyamuk tersebut menghisap darah manusia berulang-ulang pada siang hari (Chahaya, 2003).

Upaya-upaya untuk mencegah penyakit tersebut telah banyak dilakukan, di antaranya dengan pengendalian nyamuk itu sendiri maupun perlindungan terhadap gigitan nyamuk (Tawatsin et $a l$, 2001). Upaya tersebut di antaranya dengan memasang kawat kasa pada jendela rumah, memasang kelambu tidur, menggunakan obat nyamuk oles, semprot, bakar, dan elektrik (Sutanto dan Purnomo, 1990). Menurut Rui et al. (2003) dalam Kardinan (2007), menyatakan cara menghindari nyamuk yang paling baik adalah dengan pemakaian anti nyamuk berbentuk lotion, cream, ataupun pakaian yang dapat melindungi tubuh dari gigitan nyamuk. Penggunaan anti nyamuk merupakan tindakan yang praktis dan ekonomis untuk mencegah penyakit-penyakit yang dibawa oleh nyamuk ke manusia. Tetapi kebanyakan formula produk anti nyamuk yang beredar di pasaran mengandung DEET (N,N-dietil-meta-toluamid) (Katadi dkk, 2015). Penggunaan DEET dengan konsentrasi yang tinggi dilaporkan banyak memiliki efek samping seperti gejala hipersensitifitas, iritasi dan urtikaria. Setelah penggunaan yang berulang dan dalam jangka waktu lama, absorbsi melalui kulit dapat menyebabkan keracunan sistemik. Hal ini terutama terjadi pada anak-anak. (Katadi dkk, 2015). Untuk menghindari efek negatif tersebut, banyak penelitian yang telah dilakukan terhadap anti nyamuk yang berasal bahan alam (ekstrak tanaman) untuk menggantikan DEET.

Salah satu tanaman yang memiliki potensi sebagai anti nyamuk adalah minyak sereh wangi (Citronella Oil). Sereh wangi mengandung minyak atsiri dengan komponen geraniol (20-40\%), citronellal (25-50\%), dan citronellol (10-15) yang menimbulkan aroma, sehingga dapat digunakan sebagai repelen atau penangkal nyamuk (Agusta,
2000). Minyak sereh selain digunakan sebagai anti nyamuk atau repelen, juga digunakan dalam bidang kosmetik yaitu sebagai bahan utama dalam pembuatan lotion kulit dan sabun.

Minyak sereh selain digunakan sebagai repelen, dapat juga digunakan dalam bidang kosmetik yaitu sebagai bahan utama sabun, lotion kulit, dan parfum. Pada individu tertentu dengan kulit sensitif penggunaan kosmetik yang mengandung minyak sereh dapat menyebabkan iritasi kulit. Selain sebagai repelen dan kosmetik minyak sereh juga digunakan untuk antiseptik, aromatherapy, penyegar dan pengharum ruangan (Essential oils, 2010). Setyaningsih dkk (2016) melaporkan bahwa minyak sereh wangi (Citronella Oil) bertindak sebagai insektisida alami yang murah dan efektif dalam mengusir nyamuk serta dapat digunakan secara aman dan praktis, sehingga dapat dikembangkan menjadi lotion anti nyamuk.

Lotion adalah emulsi cair yang terdiri dari fase minyak dan fase air yang distabilkan oleh emulgator, mengandung satu atau lebih bahan aktif di dalamnya. Lotion dimaksudkan untuk pemakaian luar kulit sebagai pelindung. Konsistensi yang berbentuk cair memungkinkan pemakaian yang cepat dan merata pada permukaan kulit, sehingga mudah menyebar dan dapat segera kering setelah pengolesan serta meninggalkan lapisan tipis pada permukaan kulit (Lachman dkk., 1994).

Pemilihan sediaan lotion ini dikarenakan minyak sereh dapat bertindak sebagai insektisida yang efektif dalam mengusir nyamuk dan akan lebih praktis jika digunakan dalam bentuk lotion (Setyaningsih dkk, 2016). Setelah dilakukan formulasi akan dilakukan evaluasi fisik terhadap kualitas lotion citronella, meliputi uji organoleptis, $\mathrm{pH}, \mathrm{BJ}$, persebaran, homogenitas, dan ukuran partikel. Tujuan penelitian ini adalah mengetahui formulasi lotion dari bahan aktif oleum citronella dan hasil stabilitas fisik minyak sereh yang diformulasikan dalam bentuk sediaan lotion.

\section{METODE PENELITIAN}

\section{Waktu dan Tempat Penelitian}

Penelitian ini di lakukan di Laboratorium Teknologi Farmasi STIKES RS Anwar Medika yang terletak di Jalan Raya By Pass Krian KM. 33 Kabupaten Sidoarjo. Penelitian ini dilakukan selama 1 bulan mulai 29 Mei - 29 Juni 2018.

\section{Bahan dan Alat}

Bahan yang digunakan dalam pembuatan lotion minyak sereh antara lain oleum citronella, asam stearat, parafin liquid, BHT, giserin, TEA, nipagin, dan aquadest. 
Alat yang digunakan antara lain mortir dan stamper, gelas ukur, beaker glass, corong glass, gelas arloji, neraca analitik, kertas perkamen, pipet tetes, batang pengaduk, sudip, cawan porselin, sendok penyu, waterbath, hotplate, $\mathrm{pH}$ stik universal, piknometer dan kaca objek.

\section{Formulasi Sediaan}

Tabel 1. Formulasi sediaan lotion minyak sereh

\begin{tabular}{llc}
\hline Komponen & Fungsi & Kadar \\
\hline $\begin{array}{l}\text { Minyak } \\
\text { sereh }\end{array}$ & Zat aktif & $18 \%$ \\
\hline Asam Stearat & Emulgator & $5 \%$ \\
\hline $\begin{array}{l}\text { Parafin } \\
\text { Liquid }\end{array}$ & Emollient & $4 \%$ \\
\hline BHT & Antioksidan & $0,1 \%$ \\
\hline Gliserin & Humektan & $8 \%$ \\
\hline TEA & Emulgator & $1 \%$ \\
\hline Nipagin & Pengawet & $0,5 \%$ \\
\hline Aquadest & Pelarut & $\begin{array}{c}\mathrm{Ad} \\
100 \%\end{array}$ \\
\hline
\end{tabular}

\section{Pembuatan Lotion Minyak Sereh}

Langkah pertama dalam pembuatan lotion minyak sereh adalah dilebur fase minyak yaitu asam stearat, parafin liquid, BHT dan oleum citronella dalam cawan porselen. Kemudian dilebur fase air yaitu gliserin, TEA, nipagin dan aquadest dalam cawan porselen, selanjutnya siapkan mortir panas. Setelah fase minyak dan fase air pada masing-masing cawan porselen terlebur, masukkan fase minyak dan fase air secara bersamaan ke dalam mortir panas dan aduk dengan konstan hingga terbentuk masa lotion atau hingga suhu pada mortir turun. Masukkan ke dalam wadah sediaan.

\section{Evaluasi Fisik Sediaan Lotion \\ Uji Organoleptik}

Pemeriksaan organoleptik terhadap lotion minyak sereh dilakukan dengan mengamati tekstur, warna, dan aroma secara indrawi.

\section{Uji $p H$}

Pengujian $\mathrm{pH}$ dilakukan dengan menggunakan $\mathrm{pH}$ stik universal. Lotion minyak sereh dioleskan pada pH stik universal kemudian hasilnya dibandingkan dengan standard warna pada kemasan $\mathrm{pH}$ stik universal. Dicatat hasil $\mathrm{pH}$ lotion minyak sereh.

\section{Uji Homogenitas}

Pengujian homogenitas terhadap lotion citronella dilakukan dengan mengambil sedikit sampel sediaan formula lotion citronella, kemudian diletakkan sedikit lotion diantara kedua kaca objek. Di amati susunan partikel-partikel kasar atau ketidakhomogenan (Mardikasari dkk, 2016).

\section{Uji Daya Sebar}

Pengujian daya sebar lotion minyak sereh dilakukan dengan mengambil sedikit sampel sediaan dan diletakkan di tengah kaca arloji. Ambil kaca bulat lain, letakkan diatas sediaan lotion dan diamkan selama 1 menit, kemudian diameter penyebarannya dicatat.

\section{HASIL DAN PEMBAHASAN}

Minyak sereh wangi dapat digunakan sebagai penolak gigitan nyamuk. Larutan sereh wangi mengandung sitronela (35\%) dan geraniol (35-40\%). Zat sitronelal ini memiliki sifat racun kontak. Sebagai racun kontak, ia dapat menyebabkan kematian akibat kehilangan cairan secara terus-menerus sehingga tubuh nyamuk kekurangan cairan hal ini dapat terjadi setelah nyamuk mencium aroma ekstrak sereh wangi, tanaman ini mempunyai aroma yang sangat wangi akan menyebabkan nyamuk menolak karena baunya (Pinardi et al, 2010).

Sediaan dengan bahan aktif oleum citronella dibuat dalam bentuk sediaan lotion bertujuan untuk mempermudah pasien dalam penggunaan dan lebih praktis. Minyak sereh juga sering digunakan sebagai penolak serangga alami. Kemampuan menolak nyamuk telah dibuktikan melalui penelitian terhadap nyamuk Aedes aegypti maupun Culex quinquefasciatus dengan cara mengoleskan formula penolak nyamuk yang mengandung minyak sereh di kulit selama 60 menit uji. Hasil pengujian mengindikasikan bahwa minyak sereh wangi efektif digunakan sebagai penolak nyamuk (Kim et al, 2005).

Langkah pertama dalam pembuatan lotion citronella antara lain lebur fase minyak yaitu asam stearat, parafin liquid, BHT dan oleum citronella dalam cawan porselen A. Lebur fase air yaitu gliserin, TEA, nipagin dan aquadest dalam cawan porselen B, selanjutnya siapkan mortir panas. Pada fase minyak, oleum citronella merupakan bahan aktif dari formulasi lotion citronella, asam stearat berfungsi sebagai emulgator untuk menurunkan tegangan antar muka antara minyak dan air dengan membentuk film yang liat mengelilingi tetesan terdispersi sehingga mencegah koalesensi dan terpisahnya fase terdispersi (Parrot, 1971). Parafin liquid berfungsi sebagai emollient dan pengatur viskositas sehingga dapat memberikan sensasi lembut dan halus pada kulit juga membantu mengurangi kehilangan kelembapan pada kulit (Syarif, 2016).

Butyl Hydroxytoluene (BHT) berfungsi sebagai antioksidan yang banyak digunakan untuk mencegah oksidasi dalam cairan (misalnya bahan bakar, minyak) dan bahan lainnya di mana radikal bebas harus dikendalikan (Anonim, 2015). Sedangkan pada fase air, gliserin berfungsi sebagai humektan untuk memberikan kelembapan pada kulit sehingga banyak digunakan dalam pembutan sabun 
dan lotion (Ahmad, 2018). Triethanolamine (TEA) berfungsi sebagai emulgator, nipagin berfungsi sebagai pengawet bertujuan untuk menghambat pertumbuham mikroorganisme dalam suspensi pada saat penyimpanan (Rowe et al, 2006), dan aquadest berfungsi sebagai pelarut. Setelah fase minyak dan fase air pada masing-masing cawan porselen terlebur, masukkan fase minyak dan fase air secara bersamaan ke dalam mortir panas dan aduk dengan konstan hingga terbentuk masa lotion atau hingga suhu pada mortir turun. Masukkan ke dalam wadah sediaan.

Tabel II. Hasil Pengamatan Lotion Citronella

\begin{tabular}{lll} 
Pemeriksaan & Spesifikasi & Pengamatan \\
\hline \multirow{3}{*}{ Organoleptis } & $\begin{array}{l}\text { Warna : Putih } \\
\text { Bau : Khas } \\
\text { citronella } \\
\text { Tekstur: Lembut }\end{array}$ & $\begin{array}{l}\text { Warna : Putih } \\
\text { Bau : Khas } \\
\text { citronella } \\
\text { Tekstur: Lembut }\end{array}$ \\
\hline $\mathrm{pH}$ & 7 & 7 \\
\hline Persebaran & Homogen & Homogen \\
\hline Homogenitas & Homogen & Homogen \\
\hline
\end{tabular}

Uji evaluasi formulasi lotion citronella dilakukan satu minggu setelah pembuatan. Pengujian organoleptik dapat memberikan indikasi kebusukan, kemunduran mutu dan kerusakan lainnya dari produk (Eka, 2018). Hasil dari uji organoleptis lotion citronella yaitu lotion memiliki warna putih, berbau khas citronella dan memiliki tekstur lembut.

Pengukuran $\mathrm{pH}$ merupakan salah satu pengujian penting dan sering digunakan dalam analisis air. $\mathrm{pH}$ merupakan faktor penting dalam menentukan sifat kimia dan biologi air. Ini mempengaruhi bentuk kimia dan dampak lingkungan dari berbagai zat kimia dalam air (Anonim, 2015). Pada uji pH dilakukan pengukuran dengan menggunakan $\mathrm{pH}$ meter, lotion citronella tidak mengalami perubahan yaitu $\mathrm{pH}$ 7. Namun menurut Schmitt (1996), pH untuk skin lotion adalah berkisar 3,5-5,5. Sedangkan menurut Setyaningsih dkk (2016) $\mathrm{pH}$ skin lotion penolak nyamuk berkisar 3,47-5,61, dan $\mathrm{pH}$ skin lotion (standar) adalah 5,82.

Uji daya sebar merupakan kemampuan basis dan zat aktif menyebar ke permukaan kulit untuk memberikan efek terapi. Uji daya sebar dilakukan untuk mengetahui luas penyebaran saat lotion di aplikasikan pada kulit (Ririn, 2014). Sehingga didapatkan hasil bahwa sediaan lotion citronella pada konsentrasi $18 \%$ tersebar secara merata atau homogen. Hal tersebut dibuktikan dengan pengamatan partikel lotion dibawah mikroskop yang tersebar secara merata atau homogen. Sedangkan menurut Anief (2000), lotion yang paling baik penyebarannya adalah pada konsentrasi $20 \%$ sebab semakin besar nilai penyebaran sediaan maka semakin mudah sediaan tersebut untuk di oleskan.

Uji homogenitas dilakukan dengan dua cara yaitu cara pertama dengan meletakkan sedikit sediaan pada kaca transparan dan kedua dengan cara mengoleskan sampel pada tangan, hasil pemeriksaan homogenitas menunjukkan bahwa pada sediaan lotion anti nyamuk dengan konsentrasi citronella sebesar $18 \%$ tidak memperlihatkan adanya butir-butir kasar pada kaca transparan dan pada tangan saat di oleskan. Hasil penelitian dari Suprianto dan Endang (2016), uji homogenitas lotion anti nyamuk dengan bahan aktif ekstrak daun kenikir (Cosmos caudatus) pada konsentrasi $0 \%$ dan 5\% tidak memperlihatkan adanya butir-butir kasar pada saat sediaan dioleskan pada kaca transparan, sedangkan pada sediaan lotion anti nyamuk dengan konsentrasi $10 \%$ dan 15\% terdapat butir-butir kasar dari bahan-bahan yang berupa serbuk.

\section{SIMPULAN}

Formulasi yang digunakan dalam lotion citronella antara lain oleum citronella sebagai bahan aktif, asam stearat dan TEA sebagai emulgator, parafin liquid sebagai emollient, gliserin sebagai humektan, BHT sebagai antioksidan, nipagin sebagai pengawet dan aquadest sebagai pelarut.

Uji evaluasi yang dilakukan pada formulasi sediaan lotion citronella antara lain uji organoleptis dengan hasil lotion berwarna putih, memiliki bau khas citronella dan bertekstur lembut. Uji BJ dengan hasil berat jenis lotion citronella yaitu 23,8 . Uji pH yaitu lotion citronella memiliki $\mathrm{pH} 7$. Uji persebaran yaitu semua komponen lotion tersebar secara merata atau homogen. Uji ukuran partikel yaitu diketahui bahwa ukuran partikel lotion citronella seragam dan uji homogenitas diperoleh hasil bahwa lotion citronella homogen.

\section{DAFTAR PUSTAKA}

Agusta, Andria. 2000. Minyak Atsiri Tumbuhan Tropika Indonesia. ITB Press. Bandung

Ahmad, Dadan. 2018. Pengertian dan Kegunaan Glisrin. www.sridianti.com/pengertiangliserin-dan-kegunaannya.html. Diakses tanggal 25 Juni 2018

Anief, M. 2000. Farmasetika. Gadjah Mada University Press. Yogyakarta

Anonim. 2015. Sampling \& Analisis. www.sampling-analisis.com/ 2015/09/cara- 
uji-ph-dalam-air-menggunakan-

ph.html?m=1. Diakses tanggal 24 Juni 2018

Chahaya, Indra. 2003. Pemberantasan Vektor Demam Berdarah di Indonesia. Fakultas

Kesehatan Masyarakat Universitas Sumatera Utara. Medan

Eka, Adelia. 2018. Uji Organoleptik. www.academia.edu/12273406/uji organole ptik.Diakses 24 Juni 2018

Kardinan, A. 2007. Tanaman Pengusir dan Pembasmi Nyamuk Vol III. Agro Media Pustaka. Jakarta

Katadi, Syaiful., Ahmad Zaeni., Suryani., Rini Hamsidi. 2015. Formulasi Losio Antinyamuk dengan Zat Aktif Minyak Atsiri Lantana camara Linn. Jurnal Farmasi dan Ilmu Kefarmasian Indonesia. Kendari

Kim, Kyu J., Kang CS., Lee JK., Kim YR., Han HY., Yun HK. 2005. Evaluation of Repellency Effect of Two Natural Aroma Mosquito Repellent Compounds, Citronella and Citronellal. Journal Entomol. 35 (2):117-120

Lachman L, Lieberman HA, Kanig JL. 1994. Teori dan Praktek Farmasi Industri Edisi Ketiga. UI Press. Jakarta

Mardikasari, S. A., Mallarangeng, A. N. T. A., Zubaydah, W. O.S., Juswita, E. 2016. Formulasi dan Uji Stabilitas Lotion dari Ekstrak Etanol Daun Jambu Biji (Psidium guajava L.) sebagai Antioksidan. Jurnal Farmasi, Sains, dan Kesehatan, 3(2), Hal. 28-32.

Parrott, E.L. 1971. Pharmaceutical Technology Fundamental Pharmaceutics, $3^{\text {th }}$. Burgess Publishing Company, Minneapolis, p. 76-82.

Pinardi, T., Hery K., M. Yulianto. 2010. Pengaruh Larutan Sereh Wangi dan Daun Tembelekan terhadap Daya Tolak Gigitan Nyamuk Aedes aegypti. Jurnal Penelitiam Kesehatan Suara Forikes Vol 1 (1): 2086-3098

Ririn Karina H. 2014. Formulasi dan Uji Sifat Fisikokimia Sediaan Losio dengan Berbagai Variasi Konsentrasi Vitamin E. Fakultas Kedokteran Universitas Tanjungpura. Pontianak
Rowe, R.C., P.J.Sheskey, and P.J.Weller. 2006. Handbook of Pharmaceutical Excipient $5^{\text {th }}$ ed. The Pharmaceutical Press. London

Rui, X., B. Donald and A. Arshad. 2003. Laboratory Evaluation of Eighteen Repellent Compounds as Larvacides of Aedes aegypti, Anopheles quadrimaculatus and Culex quiquefasciatus. Agriculture Research Service. United States Departemen of Agriculture

Schmitt, W.H. 1996. Skin Care Products. Di dalam DF Williams and WH Schmitt (Ed). 1996. Chemistry and Technology of Cosmetics and Toiletries Industry. Ed ke-2. London: Blackie Academy and Professional.

Setyaningsih, Dwi., Erliza Hambali., dan Muharamia Nasution. 2016. Aplikasi Minyak Sereh Wangi (Citronella Oil) dan Geraniol dalam Pembuatan Skin Lotion Penolak Nyamuk. Jurnal Teknologi Industri Pertanian. Bogor

Suprianto dan Endang Subekti. 2016. Formulasi dan Uji Efektivitas Sediaan Lotion Anti Nyamuk Ekstrak Daun Kenikir (Cosmos caudatus). Institut Kesehatan Helvetia. Medan

Sutanto, B.A. dan Purnomo. 1990. Pemakaian Repelen Komersial yang Mengandung Toluamide Terhadap Culex quinquefasciatus di Jakarta. Medika. Jakarta

Suwito. 2010. Bioekologi Nyamuk Anopheles di Kabupaten Lampung Selatan dan Pesawaran : Distribusi Spasial, Keraaman, Karakteristik Habitat dan Kepadatan. Bogor Program Pascasarjana. Institut Pertanian Bogor

Syarif, Echa Alifyanty. 2016. Emolien. www.scribd.com. Diakses tanggal 25 Juni 2018

Tawatsin, Apiwat \& Thavara, Usavadee \& Wongsinkongman, Prapai \& Bansidhi, Jaree \& Boonruad, Thidarat \& Chavalittumrong, Pranee \& Soonthornchareonnon, Noppamas \& Komalamisra, Narumon \& Mulla, Mir. (2006). Repellency of essential oils extracted from plants in Thailand against four mosquito vectors (Diptera: Culicidae) and oviposition deterrent effects against Aedes aegypti (Diptera: Culicidae). The Southeast Asian journal of tropical medicine and public health. 37. 915-31. 